FOLIA POMERANAE UNIVERSITATIS TECHNOLOGIAE STETINENSIS

Folia Pomer. Univ. Technol. Stetin., Oeconomica 2017, 335(87)2, 71-80

Stanisław HOŃKO

\title{
KRYTERIA OCENY OSIĄGNIĘĆ DYDAKTYCZNYCH NAUCZYCIELI AKADEMICKICH
}

\section{THE CRITERIA FOR ASSESSING ACADEMIC TEACHERS' DIDACTIC ACHIEVEMENTS}

Instytut Rachunkowości, Uniwersytet Szczeciński

ul. Adama Mickiewicza 64, 71-101 Szczecin, e-mail: honko@wneiz.pl

Summary. The aim of this article is to review the rules of assessing teaching achievements published in evaluation forms of academics. The empirical part is preceded by an attempt to organize the terminology of the quality of education, as well as an analysis of the literature in the field of measuring the didactic achievements of academic teaching.

Słowa kluczowe: jakość kształcenia, osiągnięcia dydaktyczne.

Key words: quality of education, teaching achievements.

\section{WSTĘP}

Niniejszy artykuł jest kontynuacją cyklu dotyczącego oceny osiągnięć nauczycieli akademickich. Artykuł rozpoczynający cykl (Hońko 2014) został poświęcony ankietom wypełnianym przez studentów po zakończeniu cyklu kształcenia. Drugi artykuł (Hońko i Chojnowski 2015) dotyczył oceny dorobku publikacyjnego, z podkreśleniem nierównego traktowania publikacji naukowych i dydaktycznych. Ocena aktywności dydaktycznej nauczycieli, w tym nauczycieli akademickich, jest trudna do sparametryzowania. Najlepszym dowodem wysokiej jakości pracy dydaktycznej nauczycieli są osiągnięcia uczniów lub studentów. W przypadku uczniów pomiar osiągnięć dydaktycznych następuje podczas egzaminu gimnazjalnego czy maturalnego. Egzaminy te dotyczą zunifikowanej podstawy programowej, są przeprowadzane według określonego standardu, co zapewnia porównywalność osiągnięć.

Innym sposobem oceny jakości dydaktyki są osiągnięcia uczniów w olimpiadach i konkursach. Programy studiów, w odróżnieniu od zunifikowanych programów nauczania na niższych poziomach edukacji, są indywidualnie opracowywane przez uczelnie, z uwzględnieniem jedynie dość ogólnych ram kwalifikacji w danym obszarze kształcenia. W praktyce większość programów studiów ma niepowtarzalny charakter. Również liczba konkursów dla studentów jest zdecydowanie mniejsza niż dla uczniów. Wymienione czynniki utrudniają pomiar dokonań dydaktycznych nauczycieli akademickich. W związku z tym, że działalność dydaktyczna jest jednym z obowiązków pracowników nauki, podlega obowiązkowej ocenie. Wyniki tej oceny są brane pod uwagę przy podejmowaniu decyzji o dalszym zatrudnieniu nauczycieli; w mniejszym stopniu oddziałują na zdobywanie stopni i tytułów naukowych. 
Celem niniejszego artykułu jest przegląd kryteriów oceny osiągnięć dydaktycznych zamieszczanych w arkuszach okresowych ocen nauczycieli akademickich. Osiągnięcie założonego celu wymaga odpowiedzi na następujące pytania badawcze:

- Jakie narzędzia pomiaru osiągnięć dydaktycznych nauczycieli akademickich są opisane w literaturze?

- Jakie kryteria są brane pod uwagę przy okresowej ocenie osiągnięć dydaktycznych nauczycieli akademickich?

Odpowiedzi na te pytania znajdują się w kolejnych częściach artykułu.

\section{MATERIA I METODY}

W pierwszej części tekstu skupiono się na kwestiach terminologicznych, rozróżniając pojęcia jakości kształcenia, jakości kadry dydaktycznej i jakości prowadzonych zajęć. Podstawowym materiałem $\mathrm{w}$ tej części tekstu były artykuły naukowe poświęcone ocenie nauczycieli. Druga część tekstu wymagała przestudiowania arkuszy ocen pracowników naukowo-dydaktycznych, zamieszczanych na stronach internetowych wybranych uczelni. Należy dodać, że nie wszystkie uczelnie upubliczniają arkusze ocen pracowników, co prowadzi do ograniczonej możliwości wnioskowania na podstawie materiałów źródłowych.

\section{NARZĘDZIA POMIARU OSIĄGNIĘĆ DYDAKTYCZNYCH}

Punktem wyjścia do dalszych rozważań jest wyjaśnienie kwestii terminologicznych. Zgodnie z Ustawą z 27 lipca 2005 r. Prawo o szkolnictwie wyższym uczelnie mają obowiązek wdrożenia i doskonalenia systemu zapewniania jakości kształcenia (art. 66, ust. 2, pkt 3a). System ten obejmuje wiele procedur i związanych z nimi dokumentów, natomiast ocena jakości kadry akademickiej jest jednym z wielu elementów tego systemu. Przy ocenie jakości kształcenia bierze się pod uwagę nie tylko kadrę, ale również program studiów czy infrastrukturę dydaktyczną. Zdaniem autora wysoka jakość kadry akademickiej zazwyczaj przekłada się na jakość prowadzonych zajęć. W rzadkich przypadkach dobrzy nauczyciele źle prowadzą zajęcia, na przykład z powodu stresu, sytuacji losowych czy niedopasowania treści przedmiotu do ich zainteresowań naukowych.

Artykuł dotyczy pomiaru osiągnięć dydaktycznych nauczycieli (ocena aktywności), co wiąże się z oceną jakości kadry akademickiej (ocena zasobów). Do osiągnięć dydaktycznych, poza prowadzeniem zajęć, zalicza się też każdą aktywność dotyczącą procesu dydaktycznego, na przykład opracowanie materiałów do zajęć, skryptów czy udokumentowaną współpracę ze studentami.

O jakości kadry dydaktycznej jest mowa w standardach dotyczących jakości kształcenia w europejskim obszarze szkolnictwa wyższego (Standardy i wskazówki 2005). Przyjmuje się następujący standard: „[...] instytucje (uczelnie - przyp. Autor) powinny posiadać metody gwarantujące, że kadra prowadząca zajęcia dysponuje odpowiednimi kwalifikacjami i kompetencjami" (Standardy i wskazówki 2005, s. 6). Metody te powinny być dostępne dla zewnętrznych podmiotów prowadzących ewaluację procesu kształcenia. Wskazówki umożliwiające utrzymanie tego standardu są dość ogólne; sprowadzają się do następujących zaleceń (Standardy i wskazówki 2005): 
- kadra dydaktyczna powinna dysponować pełną wiedzą z zakresu wykładanego przedmiotu, doświadczeniem oraz umiejętnościami skutecznego przekazywania wiedzy w różnych warunkach dydaktycznych;

- kadra powinna mieć możliwość poznania opinii studentów na temat efektywności realizowanego procesu dydaktycznego;

- podczas rekrutacji i postępowań awansowych należy weryfikować poziom kompetencji zawodowych;

- kadra naukowa powinna mieć możliwość rozwijania potencjału dydaktycznego;

- uczelnie powinny zapewnić możliwość doskonalenia warsztatu słabszym wykładowcom, a w razie konieczności zwolnić ich z obowiązków dydaktycznych.

Niestety, nie definiuje się terminu „zapewnienie jakości”. Tłumaczy się to tym, że zastosowanie jednej definicji, obejmującej wszystkie okoliczności, jest niemożliwe. W przywołanym dokumencie, obejmującym 39 stron, termin „jakość” w różnych formach fleksyjnych pojawia się ponad 300 razy, natomiast słowo „kadra” występuje jedynie dziewięciokrotnie. Tak duża dysproporcja może świadczyć o tym, że zapewnianie jakości na uczelniach dość często sprowadza się do stworzenia procedur i oceny programów, a nie do oceny jakości kadry akademickiej.

Powstaje więc pytanie, jak należy rozumieć termin ,jakość kształcenia”. Jakość w najprostszym ujęciu oznacza zgodność z oczekiwaniami odbiorców. W odniesieniu do procesu dydaktycznego na uczelni chodzi o zgodność z oczekiwaniami interesariuszy wewnętrznych (studentów) i zewnętrznych (rynku pracy, podatników). Znaczna liczba interesariuszy sprawia, że trudno mówić o jednej grupie odbiorców (Jelonek i Skrzyńska 2010). Głównymi podmiotami, które bezpośrednio oceniają jakość kształcenia, są bez wątpienia studenci. Nie można jednak oczekiwać, że są oni zdolni do obiektywnej i kompleksowej oceny, ponieważ:

- poziom ich wiedzy i brak doświadczenia zawodowego mogą prowadzić do powierzchownej oceny, w której większe znaczenie mają odczucia niż merytoryczna treść przekazu;

- na ocenę wpływa też złożoność treści danego przedmiotu, a także zastosowany system oceniania studentów;

- studenci dość często kształcą się tylko na jednej uczelni, co utrudnia analizę porównawczą. Przedstawione kwestie, dotyczące pomiaru jakości kształcenia, utrudniają ocenę jakości kadry akademickiej, nie powodują jednak, że jest ona niemożliwa. Do czynników branych pod uwagę przy ocenie jakości kadry dydaktycznej można zaliczyć (The concept of excellence in higher education 2014):

- inspirujący charakter poszczególnych zajęć,

- stopień interakcji ze studentami,

- uporządkowanie przekazywanych treści,

- związek przekazywanych informacji z zakładanymi w ramach przedmiotu efektami kształcenia.

Jakość kadry dydaktycznej ma wpływ na poziom osiągnięć dydaktycznych. Większość opracowań odnosi się do osiągnięć uczniów, które są jednocześnie osiągnięciem dydaktycznym ich nauczycieli. Przy czym ocena nauczycieli wiąże się z większym subiektywizmem niż w wypadku oceny uczniów. Inspiruje to badaczy do poszukiwania zobiektywizowanych metod pomiaru jakości kadry dydaktycznej. 
Jednym ze sposobów jest pomiar dydaktycznej efektywności nauczycieli. W latach 70 . XX wieku badano związki między ocenami uczniów lub studentów a subiektywnymi ocenami nauczycieli przez przełożonych (Harris i Sass 2014). Na podstawie tych badań Jacob i Lefgren (2008) stwierdzili, że lepszym miernikiem jakości procesu dydaktycznego danego nauczyciela są wyniki testów uczniów w długim okresie niż ocena jego pracy przez przełożonych. W cytowanych opracowaniach używa się terminu „wartość dodana nauczyciela” (teacher value-added), co można interpretować jako syntetyczny miernik efektywności dydaktycznej danej osoby. $Z$ innych badań (Rockoff i in. 2012) wynika natomiast, że ocena nauczycieli przez przełożonych jest „wrażliwa” na nowe informacje o wynikach testów uczniów. Oznacza to, że wcześniejsze pomiary wartości dodanej nauczycieli liczą się mniej od bieżących ocen uzyskanych przez uczniów, co przekłada się zarówno na decyzje personalne, jak i na kolejne oceny uczniów. Przykładem innych badań jest projekt MET (Measures of Effective Teaching), zakładający kompleksowy pomiar efektywności dydaktycznej, obejmujący nie tylko analizę okresowych wyników uczniów w zewnętrznych testach, ale także hospitacje zajęć przez niezależnego eksperta i oceny wystawiane nauczycielowi w ankietach przez uczniów. Zorientowanie nauczycieli tylko na maksymalizację wyników testów uczniów lub studentów jest niewystarczające. W zależności od przyjętego priorytetu można wyróżnić kilka stylów pracy nauczycieli scharakteryzowanych w tab. 1.

Tabela 1. Przykładowe kategorie stylów pracy nauczycieli w powiązaniu z priorytetami

\begin{tabular}{|c|c|c|c|c|}
\hline $\begin{array}{c}\text { Typ } \\
\text { nauczyciela }\end{array}$ & Priorytet & $\begin{array}{l}\text { Ocenianie uczniów } \\
\text { w szkole }\end{array}$ & $\begin{array}{c}\text { Wyniki } \\
\text { egzaminów } \\
\text { zewnętrznych } \\
\text { zdawanych przez } \\
\text { uczniów }\end{array}$ & $\begin{array}{l}\text { Odczucia uczniów } \\
\text { zdających } \\
\text { egzaminy }\end{array}$ \\
\hline Mistrz & $\begin{array}{c}\text { rozwój } \\
\text { wychowanków }\end{array}$ & $\begin{array}{c}\text { kształtujące, } \\
\text { wspierające, rzetelne }\end{array}$ & $\begin{array}{c}\text { wysokie wyniki } \\
\text { i adekwatne } \\
\text { do poziomu uczniów }\end{array}$ & $\begin{array}{c}\text { poczucie rzetelnej pracy, } \\
\text { satysfakcja }\end{array}$ \\
\hline Tyran & $\begin{array}{l}\text { wysokie wyniki } \\
\text { egzaminów }\end{array}$ & $\begin{array}{l}\text { narzędzie presji, } \\
\text { wskazywanie } \\
\text { braków }\end{array}$ & $\begin{array}{l}\text { wysokie wyniki, lecz } \\
\text { zdają tylko bardzo } \\
\text { dobrzy uczniowie }\end{array}$ & $\begin{array}{c}\text { droga przez mękę, radość } \\
\text { z sukcesu, ale } \\
\text { i wyczerpanie, apatia }\end{array}$ \\
\hline Fachowiec & $\begin{array}{c}\text { rzetelna } \\
\text { realizacja } \\
\text { obowiązków }\end{array}$ & $\begin{array}{c}\text { uwzględniające } \\
\text { kategoryzację celów } \\
\text { nauczania }\end{array}$ & zróżnicowane wyniki & $\begin{array}{l}\text { poczucie istotnego } \\
\text { wkładu } \\
\text { w samokształcenie }\end{array}$ \\
\hline Niańka & $\begin{array}{c}\text { dobre oceny } \\
\text { wychowanków }\end{array}$ & $\begin{array}{l}\text { źródło pochwał } \\
\text { i zachęt }\end{array}$ & $\begin{array}{l}\text { wyniki relatywnie } \\
\text { niskie }\end{array}$ & $\begin{array}{c}\text { zawód, } \\
\text { rozczarowanie }\end{array}$ \\
\hline Malkontent & „mieć to z głowy” & $\begin{array}{c}\text { zakończenie } \\
\text { kolejnych etapów } \\
\text { nauki }\end{array}$ & $\begin{array}{l}\text { niewielka liczba } \\
\text { przystępujących do } \\
\text { egzaminu, wyniki } \\
\text { relatywnie niskie }\end{array}$ & $\begin{array}{l}\text { poczucie samotności } \\
\text { i niewiary w sukces }\end{array}$ \\
\hline
\end{tabular}

Źródło: Ciesielski (2008).

W dalszym ciągu zostaną przedstawione kryteria oceny osiągnięć dydaktycznych nauczycieli akademickich w wybranych polskich uczelniach. 


\section{SYSTEMY OCENY OSIĄGNIĘĆ DYDAKTYCZNYCH. PRZEGLĄD ARKUSZY OCENY OKRESOWEJ NAUCZYCIELI AKADEMICKICH}

Jak zasygnalizowano we wstępie, materiałem badawczym były zasady oceny osiągnięć dydaktycznych pracowników naukowo-dydaktycznych, dostępne na stronach internetowych uczelni. Dobór uczelni miał charakter losowy, a jedynym kryterium była dostępność formularzy ankiet. W rezultacie do próby, poza klasycznymi uniwersytetami, zostały zakwalifikowane uczelnie ekonomiczne, przyrodnicze, techniczne oraz medyczne. Warto dodać, że na niektórych uczelniach stosuje się kilka arkuszy - zróżnicowanych ze względu na stanowiska pracowników. W takich wypadkach zostały wzięte pod uwagę tylko formularze ankiet oceny pracowników naukowo-dydaktycznych nieposiadających stopnia naukowego doktora habilitowanego. Wybór tych formularzy wynikał z faktu, że ta grupa pracowników jest najbardziej aktywna dydaktycznie, a jednocześnie do jej podstawowych obowiązków należy powiększanie dorobku naukowego. Na większości uczelni ankiety zostały podzielone na części dotyczące działalności naukowej, dydaktycznej i organizacyjnej. W tabeli 2 zamieszczono skrótowo ujęte kryteria oceny działalności dydaktycznej na uczelniach objętych badaniem.

Analizując ujęte w tab. 2 kryteria oceny aktywności dydaktycznej nauczycieli akademickich, można sformułować następujące wnioski:

- na każdej uczelni jednym z elementów oceny nauczycieli akademickich są wyniki ankiet studenckich, przy czym nie zawsze z arkuszy oceny wynika, że są przeprowadzane hospitacje;

- na większości uczelni stosuje się punktowy system oceny osiągnięć dydaktycznych;

- liczba punktów możliwa do uzyskania z ankiet studenckich jest relatywnie mała, w stosunku do pozostałych obszarów aktywności dydaktycznej;

- na większości uczelni jednym z mierników aktywności dydaktycznej jest pełnienie funkcji promotora i recenzenta prac dyplomowych;

- na jednej uczelni (na Uniwersytecie Przyrodniczym w Lublinie) bierze się pod uwagę liczbę osób, które w danym roku zdobyły zaliczenie u danego nauczyciela akademickiego;

- na jednej uczelni (na Uniwersytecie Jagiellońskim) do działalności dydaktycznej zalicza się pełnienie funkcji promotora pomocniczego w przewodzie doktorskim;

- część uczelni, na przykład Politechnika Białostocka czy Akademia Techniczno-Humanistyczna w Bielsku-Białej, łączy ocenę działalności dydaktycznej z oceną działalności organizacyjnej;

- na wielu uczelniach w ramach oceny działalności dydaktycznej bierze się pod uwagę uczestnictwo w pracach zespołów ds. jakości i kształcenia,

- część systemów oceny uwzględnia przygotowanie sylabusów oraz prowadzenie nowych przedmiotów. 
Tabela 2. Kryteria oceny działalności dydaktycznej nauczycieli akademickich

\begin{tabular}{|c|c|c|}
\hline Uczelnia & Kryteria oceny & $\begin{array}{c}\text { Podana liczba } \\
\text { punktów }\end{array}$ \\
\hline $\begin{array}{l}\text { Akademia } \\
\text { Techniczno- } \\
\text {-Humanistyczna } \\
\text { w Bielsku Białej }\end{array}$ & $\begin{array}{l}\text { - publikacje dydaktyczne (podręczniki, skrypty, tłumaczenia, recenzje } \\
\text { podręczników, redakcja publikacji studentów, publikacje popularno- } \\
\text { naukowe) } \\
\text { - podnoszenie jakości nauczania (pełnienie funkcji koordynatora } \\
\text { projektów dydaktycznych, opracowanie kierunku lub specjalności stu- } \\
\text { diów, w tym autorstwo kierunkowych efektów kształcenia, przygo- } \\
\text { towanie programu kursów, wprowadzenie nowego przedmiotu, } \\
\text { przygotowanie raportu samooceny, przygotowanie oceny progra- } \\
\text { mowej kierunku, przygotowanie oceny instytucjonalnej wydziału, } \\
\text { przygotowanie materiałów do nauczania zdalnego, promotorstwo, } \\
\text { wyniki ankiet i hospitacji) } \\
\text { - zajęcia w języku obcym (zajęcia, konsultacje) }\end{array}$ & tak \\
\hline $\begin{array}{l}\text { Politechnika } \\
\text { Białostocka }\end{array}$ & jak wyżej & tak \\
\hline $\begin{array}{l}\text { Politechnika } \\
\text { Krakowska }\end{array}$ & $\begin{array}{l}\text { - } \text { autorstwo podręcznika lub rozdziałów w podręczniku } \\
\text { - przygotowanie materiałów do nauczania zdalnego } \\
\text { - opracowanie programu i prowadzenie nowego przedmiotu } \\
\text { - nadzór nad stanowiskiem laboratoryjnym } \\
\text { - promotorstwo i recenzje prac dyplomowych, udział w komisjach } \\
\text { podczas egzaminu dyplomowego } \\
\text { - prowadzenie zajęć w języku obcym, } \\
\text { - uzyskanie dodatkowych kwalifikacji, np. ukończenie studiów pody- } \\
\text { plomowych, uprawnień zawodowych } \\
\text { - uzyskanie nagród ministerialnych lub rektorskich } \\
\text { - wyniki ankiet i hospitacji }\end{array}$ & tak \\
\hline $\begin{array}{l}\text { Szkoła Główna } \\
\text { Gospodarstwa } \\
\text { Wiejskiego }\end{array}$ & $\begin{array}{l}\text { - prowadzenie wykładów w języku obcym } \\
\text { - promotorstwo zakończonej pracy magisterskiej, inżynierskiej / licen- } \\
\text { cjackiej; recenzje tych prac } \\
\text { - } \text { koordynacja i planowanie zajęć dydaktycznych na semestr studiów } \\
\text { - uzyskanie uprawnień zawodowych } \\
\text { - uzyskanie grantu dydaktycznego (np. Erasmus itp.) } \\
\text { - inne aktywności, które oceniany uważa za ważne, a które nie są objęte } \\
\text { ankietą (np. skrypty) } \\
\text { - ocena działalności dydaktycznej w ankiecie studenckiej }\end{array}$ & tak \\
\hline $\begin{array}{l}\text { Uniwersytet } \\
\text { Ekonomiczny } \\
\text { w Katowicach }\end{array}$ & $\begin{array}{l}\text { - czy pracownik wywiązał się z zadań dotyczących osiągania efektów } \\
\text { pracy dydaktycznej, które zostały wyznaczone w poprzedniej ocenie } \\
\text { okresowej? } \\
\text { - czy dotychczasowe osiągnięcia pracownika dają nadzieję na poprawę } \\
\text { jego kompetencji dydaktycznych w wyznaczonych terminach? } \\
\text { - średnia ocena z ankiet studenckich, z uwzględnieniem średniej ocen } \\
\text { pracowników danego wydziału na podstawie informacji: o liczbie } \\
\text { i rodzaju publikacji dydaktycznych, o udziale w wymianie między- } \\
\text { narodowej, o nagrodach i wyróżnieniach, które „mogą wistotny sposób } \\
\text { rzutować na ocenę postępów dydaktycznych”; także inne osiągnięcia, } \\
\text { na przykład opieka nad kołami naukowymi, prowadzenie nadobo- } \\
\text { wiązkowych zajęć czy referaty na konferencjach dydaktycznych } \\
\end{array}$ & nie \\
\hline $\begin{array}{l}\text { Uniwersytet } \\
\text { Jagielloński }\end{array}$ & $\begin{array}{l}\text { - publikacje dydaktyczne } \\
\text { - opracowanie innych pomocy dydaktycznych, na przykład instrukcji } \\
\text { do ćwiczeń, programów komputerowych, egzaminów testowych, } \\
\text { materiałów do nauczania zdalnego, nagranie filmów czy prowadzenie } \\
\text { blogów naukowo-dydaktycznych } \\
\text { - wyniki ankiet studenckich } \\
\text { - udział w projektach dydaktycznych } \\
\text { - osiągnięcia dydaktyczne ujęte w rozliczeniu wykonania godzin } \\
\text { dydaktycznych, na przykład pełnienie funkcji promotora pomoc- } \\
\text { niczego, opieka nad beneficjentem „diamentowego” grantu, opieka } \\
\text { nad wybitnymi studentami objętymi indywidualną organizacją studiów, } \\
\text { opieka nad kołem naukowym, wspólne publikacje ze studentami, } \\
\text { nagrody uzyskane przez studentów za prace pod kierunkiem } \\
\text { ocenianego nauczyciela }\end{array}$ & nie \\
\hline
\end{tabular}


Tabela 2. Kryteria oceny działalności dydaktycznej nauczycieli akademickich (cd.)

\begin{tabular}{|c|c|c|}
\hline Uczelnia & Kryteria oceny & $\begin{array}{c}\text { Podana liczba } \\
\text { punktów }\end{array}$ \\
\hline & $\begin{array}{l}\text { - inne aspekty działalności dydaktycznej, na przykład: opracowywanie } \\
\text { programu nowego kierunku/specjalności, opieka nad praktykami } \\
\text { zawodowymi studentów, udział w komisjach ds. jakości kształcenia, } \\
\text { współpraca z komisjami akredytacyjnymi, ukończenie form kształcenia } \\
\text { rozwijających kompetencje dydaktyczne }\end{array}$ & \\
\hline $\begin{array}{l}\text { Uniwersytet } \\
\text { Medyczny } \\
\text { w Łodzi }\end{array}$ & $\begin{array}{l}\text { - opis działalności dydaktycznej } \\
\text { - nadzorowanie prac studentów, uczestnictwo w egzaminach } \\
\text { - promotorstwo prac dyplomowych } \\
\text { - opieka nad kołami naukowymi, pełnienie funkcji opiekuna roku } \\
\text { - nagrody i granty dydaktyczne }\end{array}$ & nie \\
\hline $\begin{array}{l}\text { Uniwersytet } \\
\text { Przyrodniczy } \\
\text { w Lublinie }\end{array}$ & $\begin{array}{l}\text { - } \text { publikacje dydaktyczne } \\
\text { - } \text { realizacja procesu dydaktycznego (zajęcia prowadzone po raz } \\
\text { pierwszy, zaliczenie przedmiotu - za każde } 10 \text { osób, wygłoszenie } \\
\text { wykładów zamawianych, opracowanie wdrożonych programów } \\
\text { studiów/przedmiotów, dostosowywanie programów do zmienionych } \\
\text { planów studiów, promotorstwo i recenzje prac dyplomowych) } \\
\text { - } \text { konsultacje dla pracowników i studentów } \\
\text { - tłumaczenia tekstów } \\
\text { - odbycie stażu } \\
\text { - wyniki ankiet studenckich } \\
\text { - inne formy aktywności, na przykład organizacja stanowisk i przy- } \\
\text { gotowanie pomocy dydaktycznych, osiągnięcia podopiecznych w ko- } \\
\text { łach naukowych, sportowe }\end{array}$ & tak \\
\hline $\begin{array}{l}\text { Uniwersytet } \\
\text { Szczeciński }\end{array}$ & $\begin{array}{l}\text { - } \text { nagrody i wyróżnienia związane z kształceniem studentów i dok- } \\
\text { torantów } \\
\text { - czynny udział w konferencjach szkoleniowo-metodycznych w Polsce } \\
\text { (z referatem, posterem, prezentacją) } \\
\text { - czynny udział w konferencjach szkoleniowo-metodycznych za granicą } \\
\text { (z referatem, posterem, prezentacją) } \\
\text { - udział w krajowych programach doskonalących kompetencje zawo- } \\
\text { dowe związane z procesem kształcenia (staże szkoleniowe, pro- } \\
\text { wadzenie zajęć) } \\
\text { - udział w międzynarodowych programach doskonalących kompetencje } \\
\text { zawodowe związane z procesem kształcenia (staże szkoleniowe, } \\
\text { prowadzenie zajęć) } \\
\text { - opracowanie programu uruchomionych studiów podyplomowych lub } \\
\text { uruchomionych kursów dokształcających } \\
\text { - opracowania dydaktyczne niepublikowane }\end{array}$ & tak \\
\hline $\begin{array}{l}\text { Uniwersytet } \\
\text { Warszawski }\end{array}$ & $\begin{array}{l}\text { - informacja o wykonaniu pensum } \\
\text { - promotorstwo prac dyplomowych i doktorskich } \\
\text { - udział w promowaniu form dydaktycznych } \\
\text { - opracowanie programu studiów } \\
\text { - } \text { autorstwo podręczników i innych pomocy dydaktycznych } \\
\text { - wyróżnienia za działalność dydaktyczną } \\
\text { - działalność dydaktyczna za granicą } \\
\text { - zajęcia i staże dydaktyczne w innych ośrodkach naukowych w kraju } \\
\text { i za granicą } \\
\text { - opieka nad studentami } \\
\text { - inne formy działalności dydaktycznej (które należy wymienić) } \\
\text { - wyniki ankiet studenckich/doktoranckich }\end{array}$ & nie \\
\hline $\begin{array}{l}\text { Zachodniopomorski } \\
\text { Uniwersytet } \\
\text { Technologiczny }\end{array}$ & $\begin{array}{l}\text { - } \text { promotorstwo prac dyplomowych i doktorskich } \\
\text { - opracowanie pomocy dydaktycznych, na przykład podręczników/ } \\
\text { /skryptów, materiałów do zdalnego nauczania, instrukcji laborato- } \\
\text { ryjnych, prowadzenie nowego przedmiotu } \\
\text { - informacja o wykonaniu pensum } \\
\text { - informacje dodatkowe, na przykład prowadzenie zajęć na studiach } \\
\text { podyplomowych, w językach obcych, poza uczelnią, wyjazdy } \\
\text { zagraniczne, wyniki hospitacji } \\
\text { - wyniki ankiet studenckich }\end{array}$ & nie \\
\hline
\end{tabular}

Źródło: opracowano na podstawie arkuszy oceny pracowników uczelni. 


\section{PODSUMOWANIE}

Z przeprowadzonego przeglądu wynika, że ocenie podlega raczej ogólna aktywność dydaktyczna nauczycieli akademickich niż jakość prowadzonych zajęć. Czy można zatem przyjąć, że osoby bardziej zaangażowane w procesy dydaktyczne i organizacyjne lepiej prowadzą zajęcia? Wydaje się, że zaangażowanie w sprawy dydaktyczne korzystnie wpływa na jakość prowadzonych zajęć. Przygotowanie autorskich materiałów świadczy o tym, że nauczyciel jest zainteresowany efektami kształcenia i chce mieć wpływ na te efekty na podstawie własnych materiałów. Wspólne publikacje ze studentami mogą sygnalizować dobry kontakt nauczyciela z podopiecznymi, podobnie jak liczba wypromowanych prac dyplomowych. Są to jednak mierniki, które jedynie pośrednio odnoszą się do jakości prowadzonych zajęć. Jedynymi narzędziami bezpośredniego pomiaru jakości prowadzonych zajęć są wciąż ankiety wypełniane przez studentów i hospitacje. Należy podkreślić, że w wypadku studiów nie można posłużyć się w miarę obiektywnymi kryteriami oceny zewnętrznej, takimi jak egzamin maturalny. Sukcesy dydaktyczne nauczycieli akademickich dość często ujawniają się dopiero kilka lat po zakończeniu cyklu kształcenia, gdy absolwent musi zweryfikować w praktyce nabyte efekty kształcenia.

Dość powszechnie uznaje się, że ocena działalności dydaktycznej nauczycieli akademickich ma drugoplanowe znaczenie, w porównaniu z oceną osiągnięć naukowych. Należy się zgodzić z Mischke (2007), że uczelnie powinny być wzorem organizacji uczących się, co prowadzi do wniosku, że oceny okresowe pracowników naukowo-dydaktycznych powinny w równym stopniu uwzględniać funkcje uczonego i funkcje nauczyciela.

\section{PIŚMIENNICTWO}

Ciesielski L. 2008. Sukces dydaktyczny a sukces wychowawczy w procesie kształcenia w kontekście egzaminów zewnętrznych, w: Uczenie się i egzamin w oczach nauczyciela. Red. B. Niemierko, M.K. Szmigiel. Kraków, Wydaw. Tomani, 181.

Harris D.N., Sass T.R. 2014. Skills, productivity and the evaluation of teacher performance. Econ. Educ. Rev. 40, 183-204.

Hońko S. 2014. Ocena procesu kształcenia na uczelniach - diagnoza i propozycje zmian. Folia Pomer. Univ. Technol. Stetin., Oeconomica 311(75)2, 57-66.

Hońko S., Chojnowski Ł. 2015. Publikacje naukowe czy dydaktyczne - artykuł dyskusyjny. Folia Pomer. Univ. Technol. Stetin., Oeconomica 319(79)2, 91-100.

Jacob B.A., Legren L. 2008. Can principals identify effective teachers? Evidence on subjective performance evaluation in education. J. Labor Econ. 26(1), 101-36.

Jelonek M., Skrzyńska J. 2010. Jakość kształcenia w szkolnictwie wyższym - uwagi wstępne, w: Ewaluacja dydaktyki w szkolnictwie wyższym. Metody, narzędzia, dobre praktyki. Red. W. Przybylski, S. Rudnicki, A. Szwed. Kraków, Wyż. Szk. Eur. im. Ks. J. Tischnera, 20.

Mischke J.M. 2007. O problemie oceny nauczyciela akademickiego kilka spostrzeżeń, w: Informatyczne przygotowanie nauczycieli, potrzeby, przemiany, perspektywy. Red. J. Migdałek, M. Zając. Kraków, Wydaw. FALL, 100-109.

Rockoff J.E., Staiger D.O., Kane T.J., Taylor E.S. 2012. Information and employee evaluation: Evidence from a randomized intervention in public schools. Am. Econ. Rev. 102(7), 3184-3213.

Standardy i wskazówki dotyczące zapewnienia jakości kształcenia w Europejskim Obszarze Szkolnictwa Wyższego. 2005. Helsinki, Eur. Stow. Zapew. Jakości Szk. Wyż., https://dev.uni.wroc.pl/ wp-content/uploads/2016/03/Standardy-i-wskaz\%C3\%B3wki-ENQA.pdf, dostęp 2.11.2016. 
The concept of excellence in higher education. 2014. Bruksela, European Association for Quality Assurance in Higher Education AISBL 2014, http://www.enqa.eu/index.php/publications/, dostęp: 2.11.2016.

Ustawa z 27 lipca 2015 r. o szkolnictwie wyższym. DzU z 2012 r., poz. 572, ze zm. 
